\title{
The New Paradigm of Prophetic Education in the Disruption Era of Industrial Revolution 4.0
}

\author{
A Z Fitri \\ State Islamic Institute (IAIN), Tulungagung, Indonesia ${ }^{1}$ \\ \{guszain@,iain-tulungagung.ac.id ${ }^{1}$ \}
}

\begin{abstract}
The role of educators has shifted from initial function as a main source of learning to function as a facilitator. The sophistication of technology and the automation of work by relying on robots and big data is perceived to be able to answer all issues and to understand the soul of a human being needed by people who have strong psychological intelligence and character. Transformation in education is inevitable. At this stage, the new education model is proven to be better than the old education model in the context of knowledge transfer to students. Therefore, the incumbent institution will accelerate and transform the new model in education management. Administrative services must change and be changed. The increasing number of students without the support of digital technology will be increasingly ineffective. In the era of disruption, students simply enter the self-corner (Eco) to serve administrative aspects independently, then request validation from staff and leaders. This will reduce the bureaucracy which has been a barrier in almost all institutions, including educational institutions. Then the educational revolution through shifting paradigms needs to be done through (1) strengthening prophetic values, (2) changing educator mindset and strengthening character values, (3) humanizing technology in learning, (4) inclusion of information technology in study rooms, and (5) selfservices and assignments paperless tasks. The results of this study indicate that uncertainty, complexity, and anxiety are the main characteristics of the era of disruption and the era of the industrial revolution. This study perceived the disruption era not as a threat, but as an opportunity for the world of Education to innovate and develop.
\end{abstract}

Keywords: Paradigm, Disruption, Prophetic

\section{Introduction}

In recent years, many initially successful companies went bankrupt as a result of the disruption. Disruption does not attack the ordinary company. It killed great companies who are accustomed to lead the market, even a proud company like Nokia and Toshiba. When the incumbent was too preoccupied with branding and value creation by focusing on to the segment above the demand curve (with a relatively large margin), new entrants (newcomers) is actually aiming for his leg.

Disruption can be interpreted as a 'disorder, chaos, or problems of a process or system that causes can not be identified effectively'. Disruption has multiple meanings which include in a 
business context 'a change from the traditional way the industry operates, to the new, more effective way'[1]. Renald Disruption Kasali explains that disruption is a change to the mess, so it is not the origin of the change. In his book Tomorrow is Today he said that 'For visionary leaders, tomorrow is today. Reading, exploitation, and control of the future are not to do tomorrow, but today [2].

Andy Groove, as quoted by Renald Kasali realized that disruption is a theory that can be used to predict the future, instead of the wasting-time usual theory which is to be known and studied. Disruption can be regarded as a hallmark of life in the era of the industrial revolution 4.0 that works with the speed and the use of big data and super-sophisticated technology.

The 4.0 Industrial Revolution marked the emergence of a supercomputer, smart-robot, a vehicle without a driver, genetic and developmental editing neurotechnology that allows humans to optimize brain function. Klaus Schwab [3]. Founder and Executive Chairman of the World Economic Forum in his book, The Fourth Industrial Revolution, said that:

The fourth industrial revolution, however, is not only about smart and connected machines and systems. Its scope is much wider. Its simultaneous existence is a wave of further breakthroughs in areas ranging from gene sequencing to nanotechnology, from renewables to quantum computing. It is a fusion of the technologies and their interaction across physical, digital and biological domains that make the fourth industrial revolution fundamentally different from the previous revolution.

Developments in science have changed the world as the industrial revolution when the first generation of human and animal power was replaced with the appearance of the machine. The 19 th century constituted the emergence of the steam engine. This revolution recorded by history has managed to increase dramatically economy where for two centuries after the industrial revolution increased the average income per capita countries in the world into sixfold. Furthermore, the fourth generation of the industrial revolution has discovered a new pattern when disruptionlpresents technology so quickly and threatens the existence of incumbent firms. History has recorded that the industrial revolution has been widely claimed by the demise of giant corporations. Moreover, in the era of the fourth generation industry, the size of the companies is not a guarantee, but the key to successful business agility with quick achievement [4]. Instead, Djakarta Lloyd who has been sentenced to die suddenly rose and lived again, that's the dilemma disruption. The disruption began with a kind of denial deception for what had happened.

Educational response to the industrial revolution 4.0 is now visible through activity-based online education or online (in the network). One of the learning activities that take advantage of Internet access and systems developed by the Ministry of Education and Culture (MOEC) in collaboration with the Ministry of Religion Affairs (MORA) RI. His form is a Professional Teacher Education Program (PETP) in office. There are at least two systems that have been developed nowadays are (1)https://ppg.siagapendis.com/, and (2) https://ppgdaljab.spada.ristekdikti.go.id/. Both are online learning systems for students in colleges PPG set by the government through two ministries, MOEC and MORA.

However, it still created new problems because the main purpose of the online learning increased acceleration, effectiveness, and efficiency of learning itself, but the fact institutions, organizers, and lecturers are still difficult to ascertain whether this learning process can be effective and quality-guaranteed.

Many researchers found that the process of online learning has still many problems. For example, while students are answering questions in the discussion and formative tests utilizing 
the internet (Google) to answer any questions, professors are not directly able to control and supervise the ongoing activities of the learning proficiency level. It can be seen from the quality of the exact same answer from one participant to another, but online learning is to minimize this risk. In addition, the instructor (lecturer) could not determine whether the interaction/dialogue conducted in the online learning system is really controlled by the student or other subjects as his successor. Therefore, it is important to conduct studies and research on education in the era of the Industrial Revolution 4.0 in order to create a new paradigm in education and learning by promoting the prophetic spirit.

The paradigm is often interpreted as a perspective of looking at things. The term paradigm is referred to Thomas Khun's statement in his book The Structure of Scientific Revolution that paradigm is defined as the philosophical and theoretical framework. Khun scientific paradigm defines as 'scientific achievements that are universally recognized, for a time, giving the model a problem and a solution for the practice group.' Thomas Kuhn [5] discusses the relationship between paradigm and paradigm shift in the nature of science. Paradigm, the interlocking relationship between theory and methodology, is guiding what is learned based on the fact and the result of their research questions. Likewise, the basics of the epistemological paradigms generate the criteria for an acceptable methodology [6].

Kuhn suggests that paradigms exist because they serve a vital function. He explains, 'In the absence of a paradigm or some candidate for paradigm, all the facts that could possibly pertain to the development of a given science are likely to seem equally relevant'. The absence of a paradigm or something that would be the paradigm can be equally departing from the relevant facts, 'There is no historical nature which can be interpreted without theoretical and methodological belief to the selection, evaluation, and criteria'. However, though the paradigm serves vital functions, they are representations of reality rather than reality itself. In Kuhn's words, 'to be accepted as a paradigm, a theory must seem better than its competitors, but the theory was not necessary, and in fact, never, explain all the facts so that he can confront'. Thus, all of the paradigms contain anomalies and contradictions. A paradigm shift - a revolution in science - occurs when a new paradigm is proposed to resolve the critical anomalies. This is achieved among others by Copernicus, Newton, Einstein, and other great scientists. Easley [7] uses the analogy of a city to make a similar point about the structure of science. He noted that cities continue to change when the old and new structures are built rot.

As the continuous rebuilding of a city, a new structure represents the values and technology of the contemporary period, but the city always retains some of the old ones. The city is always functioning as a social system and the physical entity on one side, but on the other hand, it does not function. When dysfunction happens, social and physical rebuilding is going to complete. It suggests that there is a paradigm that guides the same community as their guiding science, and this paradigm has very similar functionality. Social paradigm, as a shared belief system, represented in the terminology of Freire [8] how we 'give the name of the world'. They are functional as it provides the 'glue' that holds society together. From them, we get the values and rules, either implicitly or explicitly, whereby society is governed.

\section{Method}


This study uses a qualitative method with a phenomenological approach to discover the meaning of data and facts in the naturalistic field. The type of this research field research is to build a concept through inductive data by grounded research. The design of this study was a case study on the in-service training program/Pendidikan Profesi Guru (PPG)at the Faculty of Tarbiyah IAIN Tulungagung.

In this research used purposive samples, including lecturers and students of the PPG, the sample was selected by a snowball sampling technique. Data collection techniques using observation, interviews, and document study. Data analysis in this study uses Spradley's taxonomic analysis [9] with the flow of research following the Miles and Huberman model including data collection, data reduction, data display, and verification/conclusion [10].

\section{Result and Discussion}

\section{Strengthening the Prophetic Values in Education}

The prophetic values are adopted in the spirit of the prophet teaching tohis message to mankind. For example, the value of siddiq(right), amanah(trustworthy), fathonah(intelligent), and tabligh(convey). The first value, siddiq, assumes that truth can be characterized as the only attitude, words, and actions, what is done in accordance with the documents on the ground. In other words, "Do what you write and write what you do". Unfortunately, this practice is still beautiful to say but difficult to do.

The second value, amanah, is defined as an attitude that upholds the principles. For someone who upholds a principle, he will work with full sincerity. For example, if they are students, they will not use the time at school except for learning and eliciting interests and talents. A teacher/faculty/ staff will use the time to carry out duties in accordance with the sole answer.

The third value, fathonah, can be translated as competencies and skills (professionalism). The fact that the practice of KKN (corruption, collusion, and nepotism) is still rife in Indonesia illustrates that organizers are not professional in carrying out an activity. It is like a building that is not in accordance with the initial sketch that eventually collapsed before the opening or an analysis of the case Kertajati airport development in Bandung Majalengka. As reported by [11] that a lot of flight cancellations caused by the passenger occupancy rate average is still below 30\%. Furthermore, in bbc.com (July 2nd, 2019) Ziva has questioned passengers from and to Kertajati Airport: "A study (airport construction) should be based on the volume of users who know the market". Alvin Lie (2019) also assess Kertajati Airport in West Java due to not having a clear concept. He also mentioned that "The airport is not planned well, so do not be surprised if the airport's designation is a lack of determination". Lack of planning has an impact on blurred concepts.

The fourth value, tabligh, means communication or delivery. In the concept of management education, sermons can be defined as an ability to share the vision, which transforms his ideas to be applied as well as possible. In this disruption, careful planning is necessary, because "if you fail to plan, you plan to fail". A good plan must be socialized and communicated. Today's trends dissemination and marketing. The emergence of start-ups, such as Tokopedia, Jualbeli.com, Berniaga.com. Olx.com and other online market places are promoted by their ability to package and present information both via the Internet and other networks.

\section{Changing Educators' Mindset and Strengthening Values of Character}


Fundamental changes need to be made because of some reasons. Firstly, educators can't possibly compete with artificial intelligence (machine) in the case of memorizing, counting, and searching for the source of reference. The machine will be much more intelligent, knowledgeable, and effective than educators because it never feels tired. Therefore, the teaching method must shift from $\mathrm{n}$ memorization towards education of values and character (prophetic), culture, wisdom, experience to social empathy, because these values can't be taught by a machine, if not then the face of education will experience a period of 'darkness in terms of moral, ethical and religious.

Secondly, educators need to start changing the teaching methods, responsive and flexible in understanding new things. Digital technology can help teachers to learn more quickly and effectively in the rapid change of digitalization. The question is whether education is now ready to change it? Do they have prepared? This is not just an issue of mere transformation from conventional to online learning.

The teaching-learning strategy in the disruption era can be undertaken firstly by changing the educational system. At least two groups, integrative education, and digital education are possible to reconstruct fundamental transformation in education. The first changes can be reached with a mixed learning system (blended learning, or often referred to as a hybrid learning). The second change is by using an online distance learning (ODL) system.

\section{Humanization of Technology in Learning}

The 'Paradox of Computer' is a term used by Elizabeth in explaining anomaly at the current time [12]. He stated that in terms of its context and purpose, a computer is kind of confusing aspects of character and influence. Its strength is proportional to its weakness. A competitive spirit from the world of computers currently illustrates that computers are useful to improve collaboration and cooperation in the workplace. The vision grandeur of how the computer can transform the way we think and learn became an irony in bright light but shallow in reality.

One of the paradoxes is when a community of educators and adult learners use the computer to determine the quality and quantity of a contribution to learning based on the computerized standards. For the educator community, however, the characteristics of computers often conflict with other sources. Computers are the "mindless tool with infinite use" in which a device is used to expand the possibility of a group to study and assist the activities. It is used to enhance the quality of life of people. At this point, a lot of books are written about the impact of this computer. Among them is written by Boden (1977) which states that the computer was not suitable for education,

\section{Investments of Information Technology in Classrooms}

Technology is inseparable from human-users in the 4.0 industrial revolution era. Technology contributes to the halls of learning both inside and outside the classroom. Teacher/lecturer at the faculty of learning technologies need to change learning orientation because technology can be accessible for every student, so they no longer need conventional face-to-face teaching. Information Computer Technology (ICT) in the late 1990s to early 2000 s became still subject in school, but this time the lesson has been removed from the curriculum because each individual is considered as having mastered it. 
Dealing with challenges above, at least there are possible several strategies that need to be undertaken. First, faculty relationships. The relationship between the faculty of engineering which has an orientation toward an industry with faculty who prepares prospective educators. It will be able to overcome the existing problems, such as educational technology majors which are not oriented in the industry, so they can work together to produce educators who have orientation and configuration in the workplace [13].

Second, the leadership within the group. leadership is needed because each faculty/department/study program has a different orientation and objectives. The main focus in dealing with the industrial revolution 4.0 must be controlled. Third, influences of institutional goals. The effectiveness of current learning is strongly influenced by the configuration of human resources and facilities. Institutional support is important to be a critical success factor to bring technology in the classrooms. Fourth, the demands of accrediting agencies. The demands of accreditation agencies also need to be considered, because of the factor of availability, adequacy, and equity of technology access into consideration in the educational institution process of accreditation [14]. The ratio of lecturers, students, and educators to access the internet should be sufficient with the available bandwidth capacity.

\section{Self Services and Paperless Tasks}

The 4.0 industrial revolution has a widespread impact. Rhenald Kasali describes an airport when he traveled to the United States [15]. In various international airports, the number of visitors began to decline, the official check-in counter also no longer exists. Now all the work attendant check-in counters at many airports have been taken over a machine that can directly address the needs of passengers, including scan engines to check passports and visas, as well as a printer for printing boarding pass and luggage tags. Machines are equipped with buttons for payment, either by credit card or cash. All are taken by the passenger.

In the context of education, administrative services are also to be changed and amended. The high number of students without having the support of digital technology will be increasingly ineffective. For example, if the first one student will take 5-10 minutes for one letter of correspondence, in the era of disruption they simply log into the corner for selfservice mailing independently for requesting validation of staff and managers. It will certainly make the process of administration and bureaucracy more effective and efficient.

Nowadays, Uber has changed the ways human beings work and created a new civilization. Uber is not a question of civilization itself. It is a new civilization which is different from previous eras. Aaron Levie explained that: "Uber is $\$ 3.5$ billion lessons in building for how the world should work instead of optimizing how the world 'does' works." It is therefore important to recognize their characteristics.

Table 1.Differences in Old and New Worlds

\begin{tabular}{lll}
\hline \multicolumn{1}{c}{ Old world } & \multicolumn{1}{c}{ New world } \\
\hline 1. Times series and linear & 1. Real-time and exponential \\
2. Owning the economy (economic & 2. Sharing economy (economic sharing, \\
possess, control, integration) & access) \\
3. On the lane economy (wait inline) & 3. On-demand economy (so desired, when \\
& 4. $\begin{array}{l}\text { it is available) } \\
\text { 4. Supply-demand single }\end{array}$ & 5. Invisible opponents. \\
5. his opponent clear &
\end{tabular}


All these things are happening because of advanced technology. First, technology has changed human civilization into a time series in real-time. If you ever learn statistical time series, you will interpolate past data to predict the future. Today's civilization is a period when big data could be directly treated and followed up for future dicision.

Second, in the past, when doing business, someone must have their own equipment. It's like a rich man who had to buy all the furniture themselves before marriage, or as foreign investors who opened the business in remote areas, have their own aircraft, hospitals, schools, teachers, sports fields, entertainment facilities, vehicles, machinery and so on.

Third, past technology does not allow freshness. It is true that we all have to stand in line, but now we can get what we want at that time (on demand). When the consumer wants, we were close to them with our products or services. The distance was dead (borderless): the stock digital, data, and the fleet have been moved closer to the location we needed.

Fourth, a supply-demand curve is at a single demand-and-supply. Now we live in the world of apps at the same time worked by dozens, even thousands of networks that accelerate disruption. So, any deals always involve a network of thousands of parties, as well as demand.

Fifth, enemies (competitors) are no longer visible. They go directly to the key objectives, to consumers, from door to door, immediately. Like Uber, Grab invisible, no flag, unmarked nothing, even using the flag belongs to someone else. It happened also in all sectors, ranging from food, tourism, sea transport, to whistle and medicine. They come from far in the global civilization, through technology and the hands of millions of people around us.

\section{Conclusion}

The prophetic education paradigm is a possibleanswer to the problems and challenges of the industrial revolution 4.0 which caused disruption in all sectors. Uncertainty, rapid change of technology, unseen competitors are effects and consequences of industrial revolution. It is a common transformation fromcentralized services to self-service. Students simply enter the self-corner to serve administrative aspects independently, then they simply asked for validation from administrators. Itwill reduce bureaucracy which has been an obstacle in almost all institutions, including educational institutions.

This paradigm shift can be undertakenthrough: (1) strengthening prophetic values, (2) changing educators' mindsets and strengthening character values, (3) humanization of technology in learning, (4) inclusion of information technology in the learning space, and (5) self-services and paperless tasks.. The results of this study point out that uncertainty, complexity, and anxiety are the main characteristics of disruption in the industrial revolution 4.0 , so the era of disruption is not as a threat but as an opportunity for innovation in the educational institutions.

\section{Referencess}

[1] dictionary cambridge. August 23, 2019.

[2] R. Kasali, Tomorrow is Today: This is the disruptive innovation Indonesian company in the face of opponents Not Invisible, 4th ed. Jakarta: Mizan, 2018.

[3] K. Scwab, The Forth Industrial Revolution. New York: Crown Business, 2016.

[4] R. Kasali, Disruption: "Tak da yang tak bisa diubah sebelum menghadapi motivasi 
saja tidak cukup", menghadapi lawan lawan tak kelihatan dalam peradahan Uber, 7th ed. Jakarta: Gramedia Pustaka Utama, 2018.

[5] Kuhn TS, The structure of scientific revolutions. Chicago: The University of Chicago, 1962.

[6] It Beder, "Dominant Paradigm, Adult Education, and Social Justice," Adult Educ. Q., vol. 7, no. 1, pp. 105-113, 1987.

[7] J. Easley, R. E. HS Broudy, and L. Krimerman, "The natural sciences and educational research: A comparison," in Philosophy of Social Science, New York: John Wiley, 1973, p. 16.

[8] Freire P, Pedagogy of the Oppressed. New York: Seabury Press, 1970.

[9] S. JP, Participant Observation. New York: Holt, Rinehart, and Winston, 1980.

[10] M. . Miles, A. . Huberman, and J. Saldana, Qualitative Data Analysis, A Methods Sourcebook, 3rd ed. USA: Sage Publications, 2014.

[11] www.tirto.id, "Bandara kertajati sepi peminat sebab konsep tidak jelas." .

[12] E. Gerver, "Humanizing Technology: Computer In Community Use and Adult Education," Plenum Press, New York and London, 1986.

[13] D. Brown, "A Study of Three Approaches for Teaching Technical Content to Preservice Teachers Education Technology," J. Technol. Educ., vol. 5, p. 15, 1993.

[14] N. Andre, R. Chin, M. Gramberg, W. Skelly, and W. Wittich, "Integrating nonteaching and teaching technology technical programs for preparing teachersarrangements that exist," Subcomm. Rep. Prep. CTTE, p. 3, 1990.

[15] R. Kasali, Disruption: tak ada yang tak bisa diubah sebelum dihadapi motivasi saja tidak cukup. Jakarta: PTGramedia Pustaka Utama, 2017. 